\title{
Pomen znanja in izobraževanja upravnih kadrov v kontekstu razvoja države in njene uprave 1
}

\author{
Janez Šmidovnik \\ Služba vlade RS za zakonodajo
}

Ker je državna oz. javna uprava - poenostavljeno rečeno - aparat države za izvajanje njenih nalog, torej državnih nalog, je s to instrumentalno vlogo uprave v sistemu države $\vee$ grobem opredeljena tudi problematika kadrov, ki delajo $\vee$ njej, in njihovo izobraževanje. Odvisno je od države, od njene koncepcije in iz nje izvirajočih nalog, ki jih opravlja, od njihovega obsega, narave, raznolikosti in zahtevnosti, pa tudi od položaja uprave $v$ sistemu države, od stopnje njene samostojnosti in odgovornosti za stanje stvari in za opravljanje nalog države. Zato je razumljivo, da se je problematika kadrov in njihovega izobraževanja v državni upravi spreminjala skupaj z razvojem države. Če sledimo razvoju moderne države, ki je nastala $v$ času absolutističnih vladarjev 17 . in 18. stoletja, lahko ugotovimo, da je temeljni znak moderne države $\vee$ nasprotju s srednjeveško fevdalno državo - poleg uvedbe stalne vojske - prav vzpostavitev profesionalne uradniške uprave. S pomočjo stalne vojske in uradniške uprave so absolutistični vladarji skušali obvladati celotni teritorij države in iz njega odstraniti fevdalno gosposko ter na vsem teritoriju izvajati svojo "prosvetljeno" politiko. To je bil čas, ko je imela večina prebivalstva status podložništva in je bila zato nasproti države brez pravic. Uradniška uprava se je imenovala "policija". Policija je delovala tajno, za zaprtimi vrati (kameralistično) in ni bila vezana na predpise; bila je neposredno v rokah vladarja in je delovala zgolj po njegovih instrukcijah. Policija je bila sicer zametek moderne strokovne uprave, vendar pa je bila ta strokovnost ozka, enostranska in omejena na vladarjeve instrukcije, zaradi česar se vprašanje posebnega strokovnega izobraževanja te uprave $\vee$ tej fazi njenega razvoja ni postavljalo.

Stvari pa so se spremenile $v$ naslednjem obdobju t. i. liberalističnega kapitalizma 19. stoletja, ki je nastopal z gesli francoske revolucije o svobodi, enakosti in bratstvu. Te ideje so vzpostavile povsem novo orientacijo glede vloge države in tudi glede njene organizacije. Država se je umaknila v vlogo "nočnega čuvaja", ki zagotavlja načeloma le red in mir in se ne vmešava niti $v$ gospodarstvo niti $\vee$ druge dejavnosti. $\checkmark$ gospodarstvu je veljal znameniti laissez faire - laissez passer. Državna uprava je bila organizirana $\vee$ petih klasičnih upravnih resorjih: notranje zadeve, zunanje zadeve,

1 Besedilo je avtor napisal in prebral leta 1993 na proslavi ob priliki ustanovitve Visoke upravne šole v Ljubljani. Besedilo objavljamo zaradi trajne aktualnosti problemov javne uprave, ki jih obravnava. 
notranja obramba, finance in pravosodje. Ta uprava ni bila več slepo orodje $\vee$ rokah vladarja, ampak je postala samostojna državna funkcija $\vee$ sistemu, organiziranem po načelu delitve oblasti. Temeljno načelo njenega delovanja je bila zakonitost. Ljudje so postali državljani s svojimi pravicami in dolžnostmi, utemeljenimi v ustavi in zakonih; država sama je vezana na te predpise; $v$ odnosu z državljani mora postopati po točno določenih pravilih (upravni postopek), po katerih ima državljan pravico in možnosti, da se brani pred nasiljem države (pritožba, upravni spor itd.).

Uprava s takimi nalogami in s takim položajem je morala biti seveda šolana. Glavno besedo $\vee$ taki upravi so imeli pravniki - podobno kot $\vee$ pravosodju. Zato se vprašanje posebnega izobraževanja za upravo tudi $\vee$ tej fazi razvoja države in njene uprave ni postavljalo. Problem se je reševal sam po sebi z uvajanjem in razvojem pravne discipline upravnega prava, ki je postalo ena izmed temeljnih pravnih disciplin na vseh pravnih fakultetah $v$ kontinentalni Evropi.

Povsem nove razmere pa so nastopile ob koncu 19. in ob začetku 20. stoletja. Koncept liberalistične države v vlogi "nočnega čuvaja" je doživel polom. Načela liberalističnega kapitalizma ustvarjajo nerazrešljive gospodarske in socialne probleme, ki so grozili s socialno eksplozijo. Država je bila prisiljena poseči $\vee$ gospodarstvo, pa tudi $\vee$ druge dejavnosti zlasti na socialnem področju. Nastopila je intervencionistična država javne blaginje (welfare state), ki je posegala $\vee$ vsa družbena področja: $\vee$ sfero gospodarstva pretežno posredno z gospodarskimi in finančnimi ukrepi, v sfero t. i. družbenih dejavnosti in materialne infrastrukture pa neposredno s prevzemom teh dejavnosti $v$ svoje roke ali pa pod svojo neposredno kontrolo. Nastalo je novo področje t. i. javnih služb, ki jih je država vključila v svojo upravo. Posledica je bila velikanski porast obsega državne uprave, ki se je zaradi ideje o državi javne blaginje začela imenovati javna uprava, torej uprava, ki dela za javni blagor in ne zgolj za državo kot sistem. Državna uprava je postala največji proizvajalec (javnih) dobrin in tudi največji delodajalec $v$ vsaki razviti družbi, in to delodajalec, ki zaposluje kadre najrazličnejših smeri in najrazličnejših kvalifikacij. Podoben porast je doživela tudi lokalna samouprava, ki je opravljala javne naloge na lokalni ravni v lokalnih skupnostih - $v$ občinah, okrajih itd. Obseg javne uprave je neprestano rasel in narašča še danes, čeprav $\vee$ najbolj razvitih državah prihaja do resnih opozoril glede "birokratizacije" družbe, ki jo povzroča tak razvoj države. Okoli 50 \% nacionalnega brutoproizvoda se $v$ razvitih evropskih državah pretaka skozi mehanizme javnega sektorja.

Očitno je, da v taki javni upravi ne zadoščajo več le pravniška izobrazba in pravniški kadri. Pravniška izobrazba je potrebna le še v manjšem delu nalog, ki so pravne narave, velikanska večina nalog $v$ javni upravi pa zahteva drugačno izobrazbo. Glede tega, kakšna naj bo ta izobrazba in kako naj se pridobiva, pa ni enotnega mnenja in tudi ne enotne prakse. $\vee$ glavnem veljata $v$ svetu glede tega vprašanja dve filozofiji.

Po eni upravno delo $v$ javni upravi ne zahteva nobene posebne, temveč le splošno izobrazbo: kajti pri upravi ne gre za kakšno posebno stroko, ki bi se je bilo mogoče naučiti v šoli; delo v upravi je tako heterogeno in interdisciplinarno, da se ga je mogoče naučiti le v praksi; upravno znanje je le nekakšna prevleka preko splošnega znanja, ki se pridobi v rednih šolah. Vsekakor je potrebno stalno dopolnilno izobraževanje ob delu, 


\section{Janez Šmidovnik \\ Pomen znanja in izobraževanja upravnih kadrov \\ $v$ kontekstu razvoja države in njene uprave}

eventualno tudi $v$ posebnih šolskih institucijah; posebna specialistična upravna izobrazba je smiselna šele na podiplomski stopnji za vodilne kadre $\vee$ upravi, torej na mestih, kjer sta zahtevnost in obseg specialnega upravnega znanja že tako velika, da ga ni mogoče pridobiti zgolj ob delu.

Po drugi filozofiji pa je posebno izobraževanje za javno upravo smiselno, koristno in tudi potrebno. Res je sicer, da upravna dejavnost ni stroka, kakršne so npr. pravo, medicina ali gradbeništvo, gotovo pa je, da je v upravi veliko del, ki zahtevajo izobrazbo posebnih strok (pravne, ekonomske, medicinske, tehničnih strok itd.). Toda večina kadrov $v$ upravi je zaposlena pri delih, ki ne zahtevajo take izobrazbe, ampak izobrazbo interdisciplinarne narave, s katero je mogoče - po kratki adaptaciji - delovati $v$ večini upravnih služb na področjih, kot so npr. notranje zadeve, narodna obramba, davčna služba, carina, finančna revizija, gradbene zadeve; vsepovsod v lokalni samoupravi, pri vseh upravnoorganizacijskih poslih $\vee$ državnem aparatu, $v$ javnih zavodih in $\vee$ javnih podjetjih ter drugih javnih institucijah. To je strokovna izobrazba, ki vsebuje elemente pravne, ekonomske, finančne, organizacijske in drugih ved ter obsega potrebno znanje o državi, o organizaciji njenih organov in služb, njihovih nalogah, njihovih sredstvih in metodah dela, njihovih pravnih pooblastilih, o postopkih, na katere so vezani, in o drugih postopkih, ki so jim na razpolago. Šolsko izobraževanje za upravo praviloma ne more biti izobraževanje za konkretna delovna mesta, temveč mora biti splošne narave in omogočati veliko zamenljivost kadrov v najširši paleti organizacij oz. služb v javni upravi. To pomeni, da je to izobraževanje nekakšnih "splošnih specialistov" za upravo, ki so sposobni opravljati naloge kjerkoli v upravnih službah, razen na tistih mestih, ki zahtevajo ozke specialiste, npr. pravnike, ekonomiste, tehnične kadre itd. Vendar tudi taki ozki "specialisti" potrebujejo dodatno upravno izobrazbo, da bi lahko uspešno delovali v upravi.

Gotovo je, da je mogoče priti do kadrov $\vee$ upravi tudi brez posebnih šol, $v$ sami praksi, z dolgoletnim delom zaposlenih, ki se učijo sami oz. jih uči delo samo. Tako je bilo na začetku poti vseh sodobnih držav. Toda to je dolgotrajna in nezanesljiva pot, ki je za sodobni, hitro se spreminjajoči svet prepočasna. Prepočasna je tudi za nove oz. mlade države, ki nastajajo in ne morejo čakati, da se njihovi kadri razvijejo sami od sebe. Upravne šole zagotavljajo načrtno in zgoščeno nabiranje selekcioniranega znanja za upravo, in sicer ne zgolj kot prevleko na znanje, ki se pridobiva $v$ splošnoizobraževalni šoli, ampak temeljitejše specializirano znanje. To so razlogi, zaradi katerih je $\vee$ sodobnih državah prevladala filozofija izobraževanja upravnih kadrov $\vee$ upravnih šolah - $\vee$ Evropi in v svetu.

Drugi razlog za organizirano strokovno izobraževanje in za upravne šole je političnosistemski razlog, ki izvira iz samostojnega položaja javne uprave $v$ sodobni parlamentarni državi. Značilno je, kakor dokazujejo podatki o upravnem izobraževanju drugod po svetu, da upravnih šol niso poznali nikjer v državah vzhodne Evrope, kjer so vladali socialistični režimi. Te so bile organizirane po načelu o enotnosti oblasti, uprava pa ni imela položaja, kot ga ima $\vee$ deželah s parlamentarno demokracijo. Po filozofiji socialističnih teoretikov - od utopičnih socialistov do Marxa in Lenina - uprava ni strokovna dejavnost, ki bi ji moral biti priznan položaj samostojne funkcije z lastno odgovornostjo, ampak je zgolj "administracija", ki je lahko le tehnični privesek politike. 
Zato $v$ teh državah nikoli ni moglo priti do ravnotežja med politiko in stroko in zato tudi ne do upravljanja, ki bi temeljilo na povratni informaciji. Ob takem upravljanju pa ne more biti kakovostnega in uspešnega funkcioniranja države in njenih organov; taka država tudi ne more nikoli postati pravna država, ker lahko pravno državo zagotavljajo le neodvisna sodišča na eni strani ter strokovno visoko usposobljena in samostojno odgovorna uprava na drugi strani. Pomisleki, ki so obstajali pri nas proti upravnim šolam, so temeljili predvsem na "socialističnem" odporu proti "administraciji" oz. "birokraciji"; praksa pa je kljub temu vseskozi dokazovala, da je bilo delovanje upravnih šol, čeprav so delovale $v$ razmeroma ozkih okvirih, koristno celo $v$ takih razmerah. Že $v$ času socializma se je pokazalo, da boj proti "birokraciji" ne more uspeti z bojem proti upravi nasploh, ampak le s prizadevanji za visoko strokovnost uprave, čemur pa so namenjene $\vee$ prvi vrsti upravne šole.

Tretji razlog za organizirano strokovno izobraževanje za upravo nam odkriva sodobni teoretični pogled na vlogo uprave kot sestavine integralnega procesa upravljanja, kakor ga prikazujeta npr. sistemska teorija in kibernetsko-informacijska teorija upravljanja. Na državo moramo gledati - enako kot na vsako drugo organizacijo - kot na sistem, ki deluje $\vee$ nekem okolju, na katerega se mora odzivati in $v$ katerem mora poskušati dosegati svoje cilje. Če hoče biti uspešna, mora zaznavati to okolje in se sproti odzivati nanj v skladu z vsakokratnimi razmerami, ki se neprestano spreminjajo. Odzivati se mora podobno, kot se odzivajo na svoje okolje živa bitja v naravi, čeprav ne samodejno, pač pa zavestno. Pri živih bitjih gre za naravno samoregulacijo, ki temelji na njihovih sposobnostih za zaznavanje in reakcijo, vgrajenih $\vee$ fiziološko zgradbo teh bitij, ki jim omogočajo, da preživijo.

Pri organizacijah gre za zavestno odločanje v procesu upravljanja; vendar pa nas narava uči - in s tem se ukvarja kibernetska znanost - da mora tudi organizacija razviti mehanizme za zaznavanje, za sprejemanje, za selekcijo in predelavo informacij (informacijskega vložka - inputa - in feedbacka) ter za njihovo predelavo v uporabne podatke; na tej podlagi pa lahko nato odločajo organi na posameznih upravljalskih ravneh organizacije. Ti mehanizmi morajo biti vgrajeni prav $\vee$ strokovno upravo, ki se $\vee$ državnih organizacijah označuje kot državna uprava. Državna uprava je strokovni aparat, katerega obstoj v organizmu države je upravičen prav s potrebo po zagotavljanju strokovnih premis za procese odločanja. Ta aparat mora biti zaseden s šolanim strokovnim osebjem in opremljen s sredstvi za strokovno delo - vključno s sredstvi za zaznavanje, zajemanje, razvrščanje in predelavo informacij $\vee$ strokovna gradiva za odločanje.

Državna uprava odloča sama v svoji pristojnosti o zadevah, ki se morajo reševati, pretežno na podlagi strokovnih premis odločanja; poleg tega pa mora zagotavljati strokovna gradiva za druge organe sistema, predvsem za vlado in za parlament. Tako vlada kot parlament sicer lahko uporabljata za svoje odločanje tudi strokovne ekspertize, ki jih naročita pri zunanjih strokovnjakih ali pri strokovnih institucijah, vendar je to lahko zgolj izjemoma. Kajti empirično je $v$ dolgoletni praksi dokazano, da je komajda kakšno zunanje gradivo lahko neposredno uporabno za potrebe vlade ali parlamenta. Zunanje institucije praviloma ne poznajo številnih okoliščin (organizacijskih, finančnih, tehničnih itd.), $v$ katerih delujeta in na katere morata pri svojem delu računati vlada ali 


\section{Janez Šmidovnik \\ Pomen znanja in izobraževanja upravnih kadrov \\ $v$ kontekstu razvoja države in njene uprave}

parlament; zlasti pa nimajo specifičnih informacij in specifičnega znanja, kot jih morajo imeti resorni upravni organi, ki opravljajo določene službe in morajo spremljati in poznati razmere na terenu. Nimajo ustreznega informacijskega vložka in tudi ne dobivajo povratnih informacij, ki so primarno informacijsko gradivo za odločanje $\vee$ državnih organih. Te informacijske tokove ima oz. jih mora imeti $\vee$ rokah državna uprava, ki neposredno izvršuje zakone ali nadzoruje njihovo izvrševanje, izvaja javne službe in različne oblike pospeševanja dejavnosti - gospodarskih in drugih - in je zato stalno $v$ stikih s t. i. terenom.

Zato je pomembno, da se strokovni aparat države skoncentrira tam, kjer je po logiki upravljalskega procesa njegovo mesto, tj. v strokovni upravi, kjer lahko pride do integracije vseh elementov (kadrovskih in tehničnih), ki lahko zagotavljajo strokovnost in učinkovitost upravljanja. Zaradi tega ni koristno, da si organi na posameznih ravneh države (npr. v parlamentu) poskušajo ustvariti lastne strokovne aparate poleg tistih $\vee$ državni upravi. To povzroča izgubljanje nacionalnih energij po eni strani, po drugi strani pa taka praksa lahko pripelje do antagonizmov in celo do blokad $\vee$ procesu upravljanja.

Navedeni razlogi govore za krepitev strokovne uprave in s tem za krepitev strokovnega izobraževanja te uprave. Brez šolanja strokovne uprave ne more biti moderne države; ne more biti niti dobre vlade niti dobre politike in tudi ne dobrih zakonov, ki jih za vlado in parlament pripravlja uprava. To je logika krožnega procesa upravljanja in vloge strokovnega elementa uprave, ki v ta proces uvaja strokovne premise.

In nazadnje, kar je celo najpomembneje: vzpostavitev samostojne države Slovenije. Z državno osamosvojitvijo se je bistveno razširil obseg funkcij nekdanje Republike Slovenije in s tem v prvi vrsti tudi obseg dela državne uprave; na zunaj je porast nalog zaradi vzpostavitve neodvisne države najočitnejši prav v porastu uprave. Obenem pa se - zaradi prehoda na sistem tržne in socialne države - močno spreminja tudi narava upravnih nalog, ki postaja čedalje zahtevnejša.

Država Slovenija mora iz nekdanjih skromnih administrativnih zametkov $\vee$ republiški upravi vzpostaviti strokovno državno upravo na povsem drugi ravni po obsegu in kakovosti ter primerljivo z drugimi državami. To velja zlasti za področje zunanjih zadev, za področje obrambe in za področje financ. Če konkretiziramo zgolj sfero javnih financ, je treba pomisliti na vrsto služb, ki jih mora imeti država, npr. carinsko službo, davčno službo, službo finančne revizije oz. kontrole itd., ki vsaka zase pomenijo obsežen upravni kolektiv, kakršnih doslej nismo bili vajeni. Kot se zdi, o tem še vedno nimamo pravih predstav niti na pristojnih mestih. Naj navedem samo primer iz nemške prakse, kjer ima na primer davčna služba, ki pokriva območje veliko kot je mesto Ljubljana, 500 zaposlenih strokovnih uslužbencev - ob vsej mogoči elektronski opremi, ki ji je na razpolago. Takih upravnih korpusov si pri nas ne moremo niti predstavljati. Vendar pa jih rabimo, ne glede na vse očitke, ki letijo na splošno na t.i. birokracijo države. Sicer bo država izgubljala vsaj desetkrat toliko, kolikor bi "privarčevala" s podstandardno upravo na določenih področjih.

Čeprav smo majhna država, potrebujemo sorazmerno veliko upravo, ker mora državna uprava tudi v majhni državi skrbeti za vsa družbena področja - podobno kot v velikih državah. Biti mora enako dobro usposobljena in enako družbeno priznana, kot je 
usposobljena in priznana $v$ državah z veliko tradicijo, $v$ katerih je samo po sebi razumljivo, da je uprava element družbenega ravnotežja in zagotovilo kakovostnega življenja in urejenosti družbenih odnosov. $V$ državah $s$ tradicijo ni treba več vsakomur posebej razlagati, zakaj je uprava potrebna in draga, pri nas pa je treba upoštevati tudi ta element. Priznana bo lahko samo dobra uprava, ki bo očitno delovala $v$ zadovoljstvo prebivalstva in gospodarstva. To bo takrat, ko bo funkcionirala tako, kot funkcionira $v$ Evropi z vso zanesljivostjo in kakovostjo strokovne birokracije v (Webrovem smislu). To pa pomeni, da ji je treba zagotoviti možnosti, da bo kakovostna, predvsem s sistematsko organiziranim izobraževanjem.

Očitno je, da je v naši stvarnosti še veliko predstav o nepomembnosti uprave, ne samo pri neinformiranih ljudeh na terenu, ampak tudi pri ljudeh, ki so prišli v politiko na sorazmerno hiter - skoraj revolucionaren - način, podobno kot so svoj čas prišli na vodilna mesta $v$ socialistični državi kadri, ki so se uveljavili v revoluciji in partizanski vojski. Kar neverjetno je, kako se kot inercija iz preteklosti vzdržujejo predstave o vsemogočnosti politike, ki lahko rešuje družbene probleme, sicer ob pomoči uprave, ki pa igra le vlogo podrejene administracije. Pomanjkljivo zasedena in nestrokovna uprava brez profesionalne hrbtenice in etike prispeva $\mathrm{h}$ krepitvi takih predstav. Zato prihaja do razglašanja načela, da se mora parlament opirati na znanje in gradiva zunanjih strokovnjakov in institucij in to celo vse pogosteje. Tradicija, da se na vodilna mesta $v$ upravi postavljajo politične osebe oz. osebe, izbrane po političnih kriterijih, se nadaljuje. Sedaj je celo normirana z zakonom o vladi v določbah, ki govorijo o državnih sekretarjih, o predstojnikih upravnih organov $\vee$ sestavi ministrstev in o predstojnikih vladnih strokovnih služb (25. in 29. člen zakona); vsi ti se zamenjujejo obenem z vlado, kar v naših razmerah pomeni, da se lahko kadrujejo le po političnih kriterijih.

Takšnim težnjam, ki so neugodne za državo Slovenijo in za njene perspektive v Evropi, je treba zoperstaviti - podobno kot v gospodarstvu - kakovost v upravi. Pri tem ima najodločilnejšo vlogo sistem izobraževanja kadrov. Če bo ta vzpostavljen z ustrezno institucijo, bodo, sicer počasi, sledili dobri rezultati. Počasi se bo v javni upravi države Slovenije začelo vzpostavljati ustrezno ravnotežje med politiko in upravo oz. med politiko in stroko, kar bo lahko zagotavljalo kvalitetno delo na področju javnih zadev. To ravnotežje je bilo vsepovsod v državah socializma porušeno v škodo stroke; za posledico pa je imelo diletantsko upravljanje - $v$ skladu z diagnozo, ki jo je že $\vee$ začetku tega stoletja postavil veliki nemški sociolog Max Weber. S samim padcem socializma se ti odnosi ne morejo spremeniti, očitno pa se tudi dejansko niso spremenili. Niso se mogli spremeniti, ker manjka ustrezna kakovost. Politika se rojeva sama od sebe - takšna ali drugačna; kakovost pa je treba ustvariti z napornimi, dolgotrajnimi, potrpežljivimi, sistematičnimi in tudi dragimi prizadevanji - $v$ prvi vrsti z upoštevanjem znanja, z izobraževanjem osebja za upravo. Z ustanovitvijo Visoke upravne šole je bil storjen važen korak; korak, ki naj bi dolgoročno zagotavljal, da gremo $v$ pravo smer; $v$ tisto, ki jo neprestano razglašamo - $v$ evropsko. 